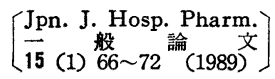

\title{
投薬㥶ロで受ける薬に関する質問の解析*1
}

清水秀行, 田中敏文, 内垣節夫

東京大学医学部附属病院薬剂部*2

\section{Analysis of Inquiries on Dispensed Drugs at the Counter of Hospital Pharmacy*1}

\author{
Hideyuki Shimizu, Toshifumi TANAKa, and Setsuo Uchigaki \\ Hospital Pharmacy, Faculty of Medicine, University of Tokyo*2
}

(Received August 11, 1988)

The counter of hospital pharmacy is an important place for expositions on drug therapy to the patients. Inquịies on dispensed drugs at the counter were studied for 4 weeks. In the period, 14,426 prescriptions were filled and 600 inquiries from 404 persons were received. Inquirers' ratio of female was higher than that of male. Sometimes inquirers were made one after another and at other times inquirer was not made more than one hour. It was shown that half of inquirers were made within 10 minutes after the former inquirer left the counter. Different inquirers' ratios were acquired in respective clinical departments and in respective days of the week. Therefore the relationship between the number of inquirers and the number of prescriptions was influenced by both clinical departments and a day of the week as confused factors. In order to lessen the influence of those factors, the data of inquirers and prescriptions were processed by means of dividing office hours into 15 parts at every 30 minutes. The result was that the number of inquirers was proportional to the number of prescriptions. $90 \%$ of pharmacists' answers to the inquirers were finished within 2 minutes.

As to content, $45 \%$ of all the inquiries were about use of drugs, and $39 \%$ about drug effect. The young patients had a tendency to make inquiries about use of drugs, and the middle-aged patients had a tendency to make inquiries about drug effect.

Keywords_ counter of hospital pharmacy; exposition on drug therapy; inquiry on dispensed drugs; relationship between inquirers and prescriptions; content of inquiry

近年, 患者への服薬指導が重視されているが，薬剤師 にとって最も身近な投薬空口に打ける患者からの薬に関 する質問についての報告は少ない、年).そこで著者らは， それらの質問と処方せん枚数との関係から現状を量的に 把握すること, 質問の内容を分類して用法指示及び空口 業務のあり方について再考することを目的として，薬に 関する質問について調査し解析する。

*1 日本薬学会第 107 年会（京都，1987年 4 月）で発 表.

*2 真京都交京区本郷 7 丁目3-1; 3-1, Hongo 7-chome, Bunkyo-ku, Tokyo, 113 Japan
調 查 方 法

東京大学病院薬剤部の外来調剂室投薬空口において, 昭和60年11月11日から 12 月 7 日までの 4 週間に受けた薬 に関する質問について調査した. 当院では午前 8 時 30 分 から 9 時まで及び午後 4 時 30 分から 5 時までの時間帯は 空口をかえて業務を行っているため, 調査は平日午前 9 時から午後 4 時 30 分, 土曜日午前 9 時から午後 1 時の間 で行った．質問には薬㶡師 4 名が随時応対した. 調査項 目は, 日付, 科名, 患者名, 年㱓, 性別, 患者または代 理の別 (代理の場合は質問者の性別), 質問内容, 及び処 万内容とした. 所要時間は, 質問を受けた時刻及び解決 
した時刻をタイムスタンプ（アマノ MODEL 2940）で 打刻し, 医師への問い合わせ，医師の所へ患者に戻って もらった時間等も含めて計測した. 質問内容は, それら のパターン及び特性によって分類した.

\section{結果及び考察}

\section{1. 問の異的な調査}

\section{（1）問者数及び問件数}

期間中の総処方せん枚数は 14,426 枚, 総質問者数は 404 人，総質問件数は600件であった．処方せん 100 枚あ たりの平均質問者数 (質問率) は 2.8 人，及び平均質問 件数は 4.2 件であった。この率は，0.97件/100枚として いる小野ら ${ }^{3)}$ の調查結果に比べて高いことを認めた.

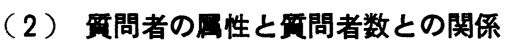

質問者を患者又は代理の別，及び性別に分類した（表 1). 男女別では, 女性が男性より多かった. 15〜39才， 40〜 59才，及び60才以上に年秢層別した質問率は，男性 では各々 $1.5,2.2$ 及び 1.6 人 $/ 100$ 枚で中年層が高く, 女 性では各々 $2.3 ， 3.2$ 及び 3.9 人 $/ 100$ 枚 で年齢層が高く なるに従って高い質問率を示した，最年少者は15才であ った，高㱓者の層においては，性別による違いが大きい ことを認めた。

\section{（3）頟問の頻度と時刻との関係}

日常投薬空口では, 連続して何人かの質問を受ける傾 向が間昡的に現れることを経験していることから，その
表 1 . 質問者数の属性別内訳

\begin{tabular}{lrrrrr}
\hline \multicolumn{2}{l}{ 患者・代理別 } & 男 & 女 & 不明 & 合計 \\
\hline 患 者自身 & 85 & 262 & - & 347 \\
\multicolumn{2}{l|}{ 患者の代理 } & 4 & 51 & - & 55 \\
不 & 明 & - & - & 2 & 2 \\
合 & 計 & 89 & 313 & 2 & 404 \\
\hline
\end{tabular}

傾向を知るため, 質問の頻度と時刻との関係を調査し た. 適当な 4 日間を図 1 に示す. その結果，集中的に質 問がある時間帯と 1 時間以上にわたって質問のない時間 带があることを認めた。

そこで質問の間隔を前の質問者の終了時刻と次の質問 者の受付時刻の差から求めた結果, 応対中への割り込み 質問を含めて 5 分未満が $33 \% ， 5$ 分以上 10 分未満が $16 \%$ を占めた. 質問の約半数が前の質問の終了後10分以内に 生じていたことを認めた.

\section{（4）啠問者数に及ぼす曜日及び揨療科の影響}

調查期間中の日毎の処方せん枚数と質問者数との関係 を平日20日間について検討したところ, 相関関係は認め られなかった $(\mathrm{r}=0.13, \mathrm{n}=20, \mathrm{p}>0.5)$. これは, 各 診療科で初診受付または特殊専門外来などを曜日を定め て行っているため, 曜日と診療科の両方が交絡した形で 質問率に影響することによると考えられた。 そこで，調 查期間中の平日 20 日間の平均では処方せん36枚あたり質

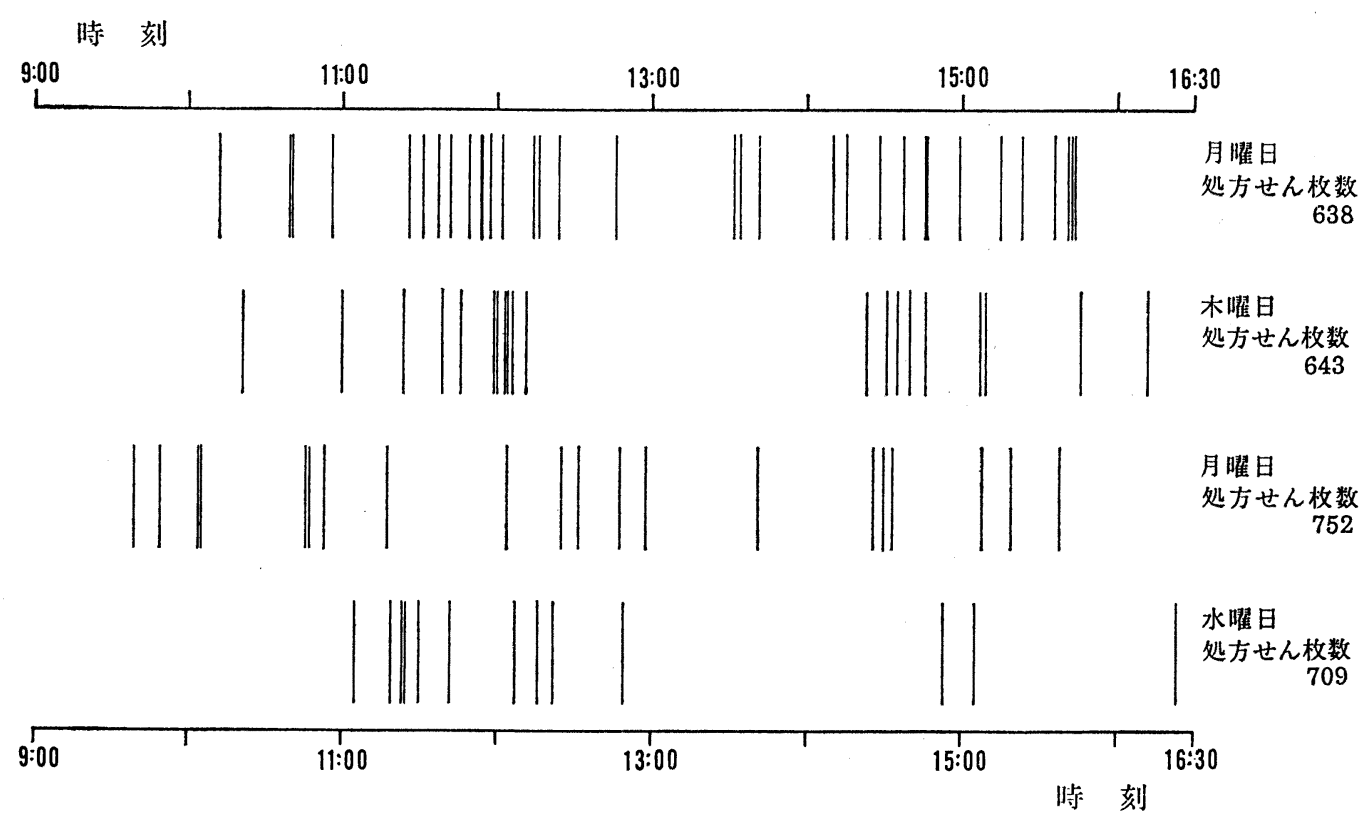

図1. 質問の頻度と時刻との関係 
問者 1 人であったことから，この值をもとに日毎の各診 療科の処方せん枚数から算出した質問者数と, 実際の質 問者数とを比較した. その結果, 多くの診療科で曜日毎 飞特定の傾向があり，当院では月曜日及び木曜日に質問 者数が増える傾向が認められた.

この他に, 初診か再診かの別, 処方変更があったか否 かの別は患者の性別, 年齢と共に複雑に交絡した形で質 問率に影響を及ぼしていると考えられる。しかし，これ らの情報を得るには患者に余分なわずらわしさを与えね ばならなかったため調査は行わなかった。

\section{（5）処方せん枚数と兵問者数との関係}

曜日別飞現れる診療科別の質問者数の増減傾向の影響 を小さくして解析するために，午前 9 時から午後 4 時 30 分までを 30 分毎の 15 の時間帯に分け，平日 20 日間のそれ らの時間帯に受け付けた処方せん枚数及び質問者数を集 計した。これらの関係を図 2 (図中の・実線)に示した.

処方せんを提出してから調剤された薬郕を受け取るま での調剤待時間を30分として, 質間者数を実際に質問を 受け付けた時刻より 30 分早めて, 処方せん枚数との関係 を調べた. 質問者数一時間曲線は処方せん枚数 - 時間曲 線と相似性を示し, 対応する値の間には有意な相関関係 $(\mathrm{r}=0.82, \mathrm{n}=14, \mathrm{p}<0.01)$ が垫められた。 また，処方 せん枚数に対する質問者数の割合が，午前に比べ午後の 方が高くなっていることが認められた。 そこで処方せん 受付時刻とその処方せんに関する質問受付時刻との関係
を調べた結果，処方せん提出が午前中であったにあかか わらず質問が午後であった例が多く見られた。これは， 患者等が午前中に調剂を依頼して，午後の適当な時間に 薬を取りに来るためと考兄られた，そこで，質問受付時 刻ではなくその処方せん受付時刻により質問者数をプロ ットした結果（図 2 中の $\boldsymbol{\Delta}$ 点線），処方せん枚数と質問 者数の間には極めて有意な相関関係 $(\mathrm{r}=0.96, \mathrm{n}=15$, $\mathrm{p}<0.01)$ が認められた.

\section{（6）問への応対所要時間}

質問に伴って処方医へ電話による問い合わせなどを行 った場合には，平均約20分を要した。しかし，質問への

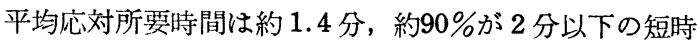
間であった。この結果は，応対時間 1 分以内が $59 \%$ を占 めたとしている米沢ら 2) の結果とほぼ一致しており，質 問者が投薬空口を占有する時間，面積が制限されている ために，いずれの報告においても短い時間であったと考 えられる。

\section{2. 僙問の兵的な調查}

\section{(1) 留問内容}

質問内容を 7 群に分類して, 総質問件数に対して各群 の数の占めた割合を図 3 亿示す.

内用薬の服用汇関する質閭件数のう号服用時期及び回 数汇関する質問がその $81 \%$ を占めて拈り，それらの大部 分が「いつ薬を飲んだらよいか」といらパターンであっ た. そのうち $91 \%$ ，服用時期の薬袋への記載が不十分

(枚)

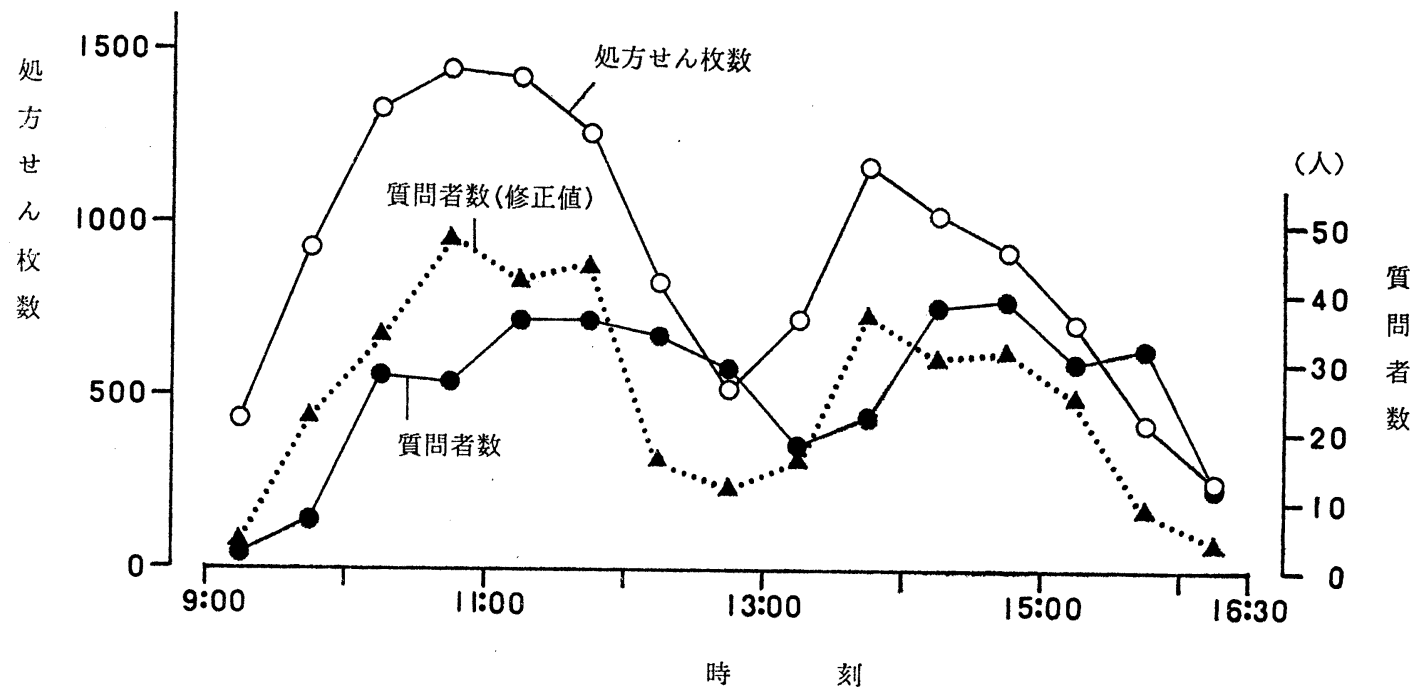

図 2. 時間帯ごこの処方せん枚数こ質問者数

質問者数：質問受付時刻により集計した質問者数

質問者数 (修正值)：処方せん受付時刻により集計した質問者数 


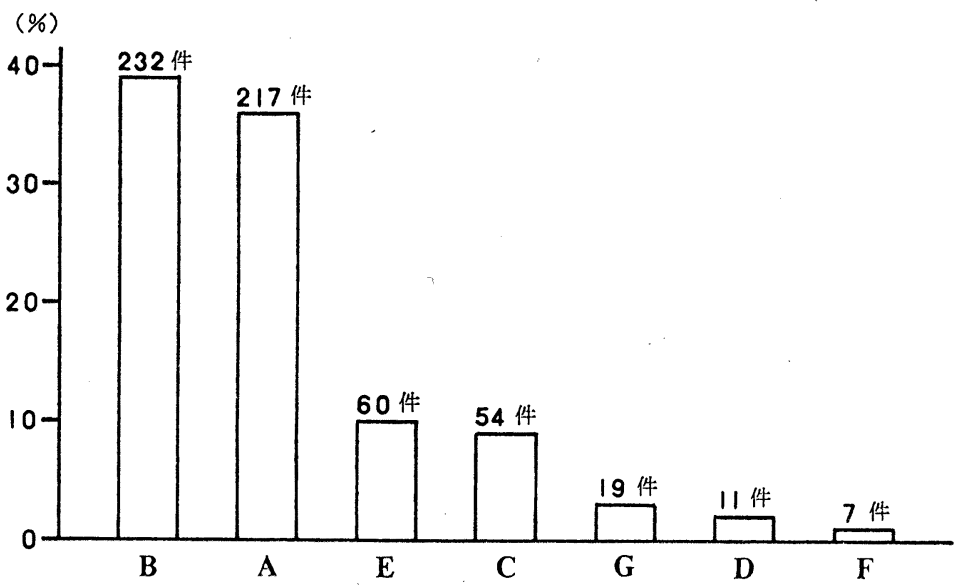

図 3. 質問内容の割合
A : 内服薬の服用に関する質問（服用時期及び回数・服用量・飲み方・ 併用・その他)
$\mathrm{B}$ : 薬剤の特性に関する質問（薬効(薬理作用)・特定薬剤の確㸾・副作 用・相互作用・薬名・その他)
C : 外用薬の使用に関する質問 (使用方法・併用・その他)
$\mathrm{D}$ ：保管に関する質問（保存（安全性）・保存方法・その他）
$\mathrm{E}$ : 処方せん記載に起因する質問（品目数の違い・薬の違い・数（量） の違い・剤形の違い・その他)
F：調剤に起因する質問（調剤過誤・その他）
$\mathrm{G}$ : その他（薬価・患者の感違い・その他）

であった，処方せんに用法記載がない場合，医師が直接 患者に用法を指示しているため, 薬袋には指示しないと いう申し合わせが服用時期の薬袋への記載が不十分であ った原因と考兄られる．用法指示については患者への口 頭による説明に加兄，処方せんに記載することが服薬遵 守に有用であることを医師に啓発する必要があると考兄 る. その他は，薬袋に記してあった抗生物質の一定時間 間隔での服用指示の解釈に関する質問があった，等間隔 服用する薬剤については，薬袋への記入に補足説明事項 が必要であると考えられる。

薬剤の特性に関する質問件数のうら, 薬効及び薬理作 用についての質問が約 $46 \%$ を占めた．説明を求められた 薬凪を薬効分類別に整理すると, 中枢神経系用薬, 消化 器官用薬に関する質問が各 $23 \%$ であった，中枢神経系用 薬では，解熱鎮痛消炎薬，及び総合感冒薬が約 $63 \%$, 消 化器官用薬では消化性潰瘍治療薬が約70\%を占めてい た．その他の薬剤では鎮咳去痰薬 $(13 \%)$ ，抗生物質製剤 (11\%) が多かった。これらの質問の多くは「何の薬で すか」といらパターンであった．特異な例として効力の 比較に関する質問があり，それは単純に薬効を質問した のち連鎖的にされた質問であった．特定薬剤の確認につ いての質問も多く約 $36 \%$ を占めて，その大部分は「○○
の薬はどれですか」というパターンであり，○○は薬効 名である場合が多かったが, 薬名, 服用時期の場合もあっ た．薬効または特定薬剤の確認に関する質問の多くは， 患者が服用する薬剂中で主な疾患用の薬剤を他と区別す るためのことと考えられ，病状が改善されたときに特定 薬剂の服用を中止することがありらるので，これらの質 問者にはコンプライアンスに関して示唆する必要がある と考えられる。

副作用についての質問は薬剤の特性に関する質問の 5 \%に過ざなかった。これは全質問件数の約 $2 \%$ に相当す る.それらは使用後に生じる副作用についての質問と， 現在副作用らしい症状がある場合とに分けられた．後者 はステロイドによる満月顔，及び抗生物質による薬疹に ついてであった．本調査で副作用に関する質問が少なか ったことに関して，それが多いことを予想したにもかか わらず $0.6 \%$ に過ぎなかったとする米沢ら 22 と同様の感 じを持った．しかし待合室に薬の相談コーナーを設けて いる施設での報告4,5) では，副作用に関する質問が 16 , 10\%であったとしている，相談コーナーでは専任の薬剤 師が待機して扣り，かつ，投薬空口に比ベプライバシー が保護される．このため，患者にとっては他の患者に聞 かれたくない副作用などの質問がしやすい環境であると 
考えられる，相互作用についての質問は $3 \%$ に過ぎなか ったとそれらは，複数科受診または多施設受診により受 け取った薬，OTC薬，または酒，牛乳との併用に関する 事項であった.

外用薬の使用に関する質問件数のらち，使用方法につ いての質問が約 $70 \%$ 占めた．また外用薬の併用に関す る質問は，すべて 2 種類以上の点眼薬が処方された場合 であった。

保管飞関する質問は少なく，それらは薬剤が使用可能 である期間, 及び以前に受け取った薬剤の使用の可否に 関する質問であった.

処方せん記載に関する質問は，従来の服用薬剤，医師 飞希望した薬剤または医師の説明による薬剤と違って いたことなどに起因する事項であった。

薬剤部として特に注目すべき調剤化関する質問のらち 過誤に起因するものは，散付錠剤での錠剤の調剂もれ， 薬袋の服用回数の記載違い, 内用液剤での計量カップの 付け忘れの 3 件であった。他の質問は，内用液剤での配 合変化防止のため組み合わせ調剤となったため投薬ビン
の数が増えたこと，分包紙がいつると違っていたこと， 及び医薬品の製造会社による包装変更に起因したもので あった。

その他に分類された質問の約 $1 / 3$ は，料金及び薬価に 関する質問であった。

\section{（2）質問者の屈性と監問内容との関保}

属性別の質問内容の割合を図 4 に示す．ただし質問内 容の分類の中で, 保管, 処方せん記載, 調剤, 及びその 他に関する質問は頻度が低いため，まとめてその他とし た.

性別による傾向として，男性では内用薬の服用につい ての質問が多く，女性では薬剂の特性汇関する質問が多 かった．年龄層別では15 39才の層で内用薬に関する質 問が多く，40〜59才の層では薬風の特性に関する質問が 多い傾向がみられた。また代理者の質問群では，特性に 関する質問が多かった．これは患者の病状把握に努める 結果によると考学られる.

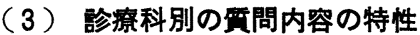

質問者数が 20 人を越えた 9 診療科について質問内容の

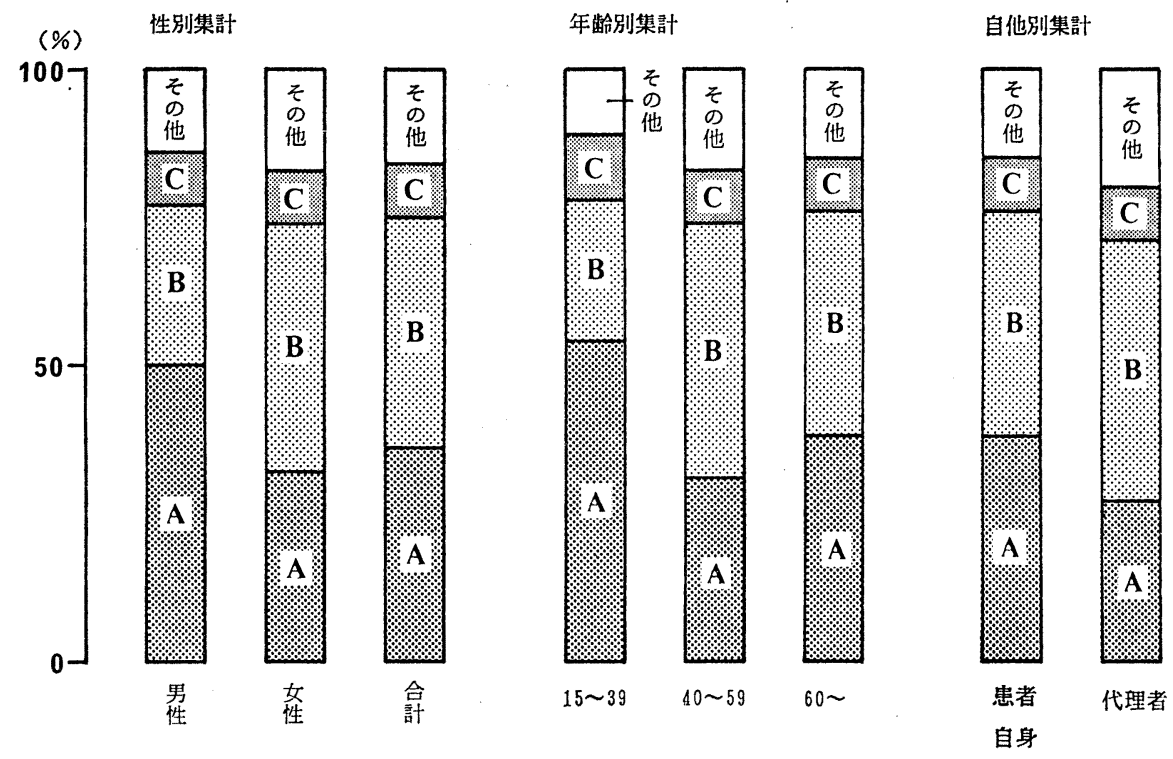

図 4. 属性別の質問内容の比率

A : 内服液の服用に関する質問（服用時期及び回数・服用量・飲み方・併用・その他）

B : 薬剤の特性汇関する質問 (薬効(薬理作用) ・特定薬剤の確認・副作用・相互作用・ 薬名・その他)

$\mathrm{C} ：$ 外用薬の使用に関する質問（使用方法・併用・その他）

その他：保管に関する質問（保存 (安全性)・保存方法・その他)

処方せん記載に起因する質問（品目数の違い・薬の違い・数（髤）の違い・骶

形の違い・その他)

調剤に起因する質問（調剤過誤・その他）

その他（薬価・患者の感違い・その他） 


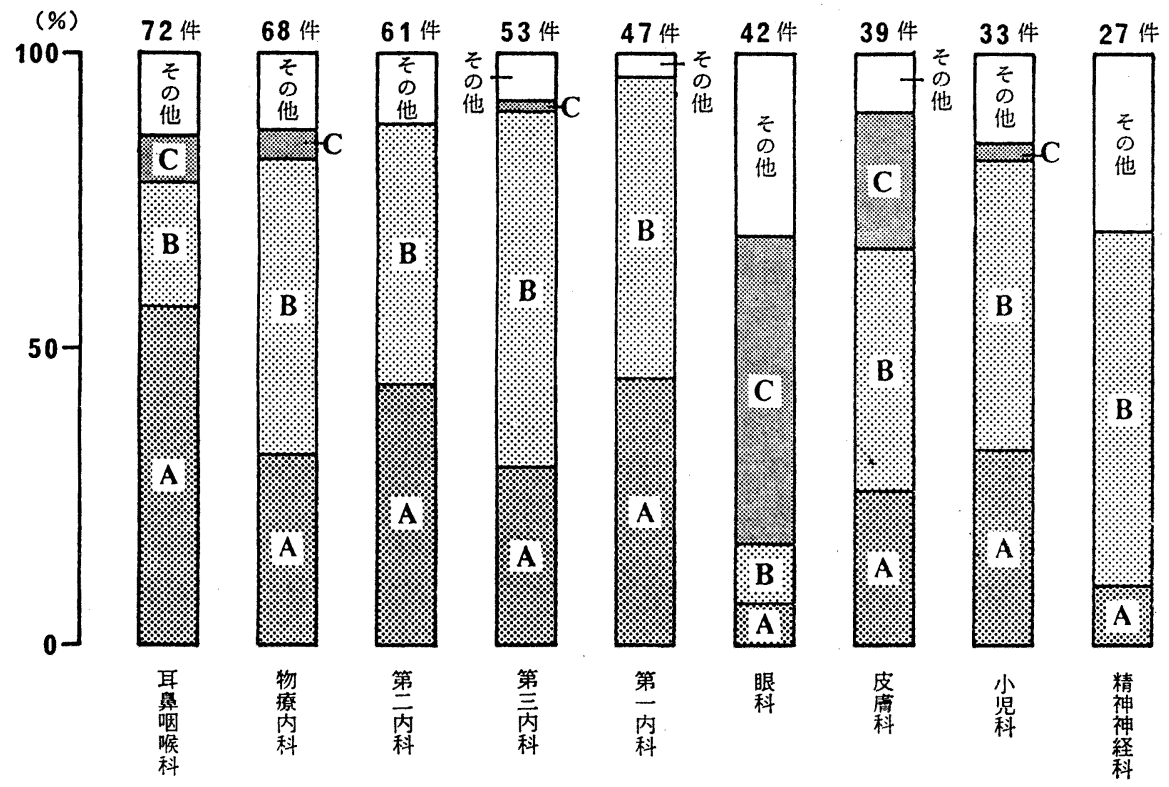

図 5.9 診療科の質問内容の比率

A : 内服薬の服用に関する質問（服用時期及び回数・服用量・・飭み方・併用・その他）

B : 薬剤の特性に関する質問 (薬効(薬理作用) ・特定薬剤の確認・副作用・相互作用・ 薬名・その他)

C : 外用薬の使用に関する質問 (使用方法・併用・その他)

その他：保管に関する質問（保存 (安全性)・保存方法・その他)

処方せん記載に起因する質問（品目数の違い・薬の違い・数（量）の違い・刻 形の違い・その他)

調剤に起因する質問（調剤過誤・その他）

その他（薬価・患者の感違い・その他）

特性を検討した（図 5 ). 前項と同様に保管，処方せん記 載, 調剤, 及びその他に関する質問は頻度が低いためま とめてその他とした.

質問件数の最も多い科は，耳鼻咽喉科であった，その $57 \%$ は内用薬の服用についての質問であり，物療内科を 含む内科系診療科より内用薬の服用汇関する質問の割合 が高かったが，薬剤の特性任関する質問の割合が低かっ た. 内科，小児科，及び精神神経科では，薬剤の特性に 関する質問の比率が高かった。そこで調查期間中の 1 週 間について処方せん中の用法記載に不備があったものの 割合を調べた結果では, 耳鼻咽喉科は一般の内科に比べ て用法記載不備の処方せんは少なかった。杉山ら 慢性疾患の多い内科では薬効, 副作用の質問が多く, 皮 虚科, 小児科, 耳鼻咽喉科では服用方法, 使用方法の質 問が多かったと報告している。これらのことから，本調 查の結果中で耳鼻咽喉科で服用淔関する質問が多かった ことは, 受診患者に内科系診療科飞比べて急性疾患患者 が多いためではないかと考えられる。また小児科で薬郕
の特性に関する質問が多かったのは，親など代理者の薬 に関する関心が高いこと，および当院では受診者中で慢 性疾患患児の率が高いことによると考えられる。

質問の内容はさまざまであった，患者への応対はその 結果がコンプライアンスに直接影響することが考兄られ ることから，いかなる内容であっても患者の利益を考兄 て応対にあたる必要がある，さらに，質問のあった患者 については処方医との情報交換を積極的に行っていく必 要があると考える.

\section{引 用 文 献}

1) 近藤由利子, 薬局, 34 (2), 193 (1983).

2）米沢健三，㛢川敦子, 鈴木 満, 水野康司, 病院 薬学, 10 (4), 286 (1984).

3）小野 彪, 千葉幹夫, 萲内徳蔵, 島川治已, 病院 薬学, $13(5), 308$ (1987).

4）山岡桂子, 中島康雄, クリニカルファーマシー, (8), 80 (1986).

5）白澤吉哲, 関銀一郎, 全田 浩, 日本病院薬郕師 会雑誌, 18 (9), 669 (1982). 
6）杉山裕子, 山下恭子, 大久保和加恵, 石倉千代治,

日本病院薬剂師会雑誌, $20(7,8), 859(1984)$.

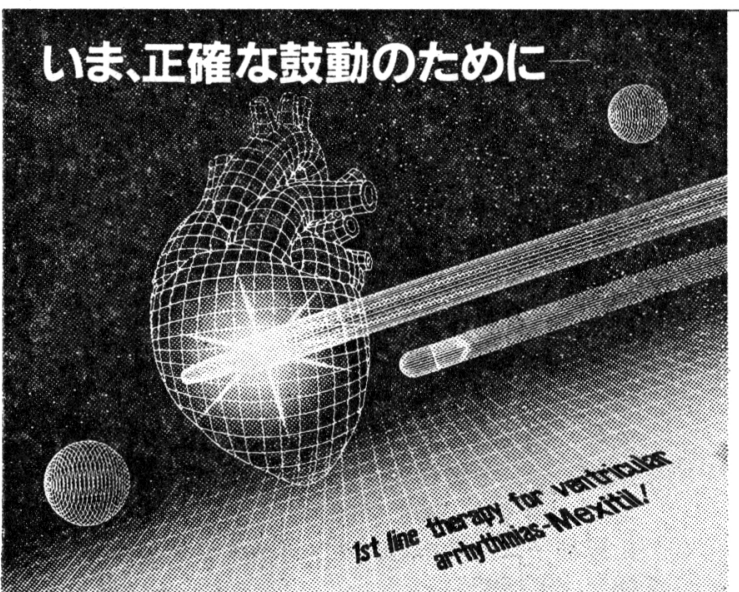

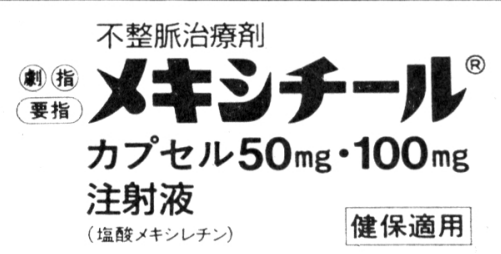

効能・効果

頻脈性不整脈(心室性)

※用法・用量、使用上の注意等については添付文書をこ覧ください

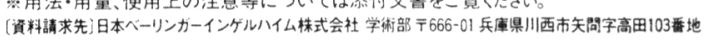

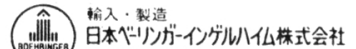

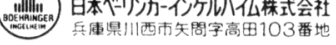

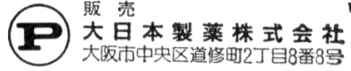

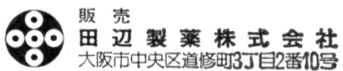
販 売 Mexiti ${ }^{\circledR}$ 